\title{
INDEBTEDNESS OF CZECH HOUSEHOLDS
}

\author{
Liběna Černohorská ${ }^{1}$, Veronika Linhartová ${ }^{2}$ \\ ${ }^{1}$ Univerzita Pardubice, Fakulta ekonomicko-správní, Studentská 95, 53210 Pardubice 2 \\ Email: libena.cernohorska@upce.cz \\ ${ }^{2}$ Univerzita Pardubice, Fakulta ekonomicko-správní, Studentská 95, 53210 Pardubice 2 \\ Email: veronika.linhartova@upce.cz
}

\begin{abstract}
Continuously growing indebtedness of Czech households is a trend of recent years. Even though the pace of the growth of credits provided to households is not currently reaching such high values as it did in previous years, still household indebtedness is growing every year and the volume of credits granted by banks exceed one billion of Czech crowns at the moment. This paper focuses on the development of the indebtedness of Czech households, its current status and the predicted future development. This topic will be analysed not only on the general level but also from the viewpoint of income and age. The aim of this paper is to analyse the development of Czech household debt at banking institutions, including a prediction of future development. The analysis will be performed using cluster analysis, which occurs in the evaluation of total household indebtedness and to the analysis of household indebtedness according to their income and age structure of the respondents.
\end{abstract}

Keywords: bank credits, bank deposits, household, indebtedness, savings.

JEL classification: D13, D14, G21

Doručeno redakci: 19.6.2012; Recenzováno: 11.2.2013; 19.2.2013; Schváleno k publikování: 19.6.2013

\section{Introduction}

For most people the possibility of obtaining a large amount of money relatively easily and fast is a temptation that they will often succumb to. Today it is very easy to apply for a loan. The most important condition is usually the client's creditworthiness, in other words the client's ability to repay the credit. Instalments may be distributed over a long period of time so that they would not represent a huge burden for households. However it is just this easy availability and a wide range of credit products made almost to measure for every client that cause that people are attracted to draw up a credit contract that will provide them with a financial sum they need in a short time - nonetheless such contract will later turn out to be unfavourable.

The objective of this paper is to give complex data on the development of household indebtedness in years 1993-2011. The executed analysis will focus not only on the causes of indebtedness, its past and expected development. It will also study the indebtedness of households from the viewpoint of their incomes and age structure. At the same time we will make a prediction about the future development of household credits and deposits for years 2012 and 2013.

\section{Development of household indebtedness}

In the course of the nineties of the 20th century significant oscillations were occurring in the sphere of granting credits to households. Within this period the level of indebtedness did not grow substantially and in some years it even slightly decreased. We see the main reasons for this in extensive economic and social changes, uncertain future and the unwillingness of banks to provide loans to minor clients. The beginning of the new millennium represented a turn in the sphere of credits granted to households. Within the last decade the volume of financial means borrowed by households increased multiple times. When seeking to identify 
the causes of this credit turning point it is logical to focus on interest rates that determine the price of the borrowed means. In this paper we consider nominal interest rates (ie interest rates specified explicitly in the contracts of loan or deposit). Interest rates demonstrated a high level of volatility in the nineties. At the end of the nineties they stabilized. At the same time there was a permanent drop in the value of interest rates. Households responded to this stabilization and the drop off interest rates by higher demand for credits (Černohorský, Serdarevic, Teplý, 2010; Hronová, Hindl, 2008)). Financial institutions made use of this situation and reacted by improving the quality and the range of the offer of services (Ministry of Finance of the Czech republic, 2009). Besides the influence of interest rates a series of studies have proved a significant influence of the GDP, PX50 index or investments on the demand on the Czech credit market. On the other hand the supply of bank institutions is a function of deposits, industrial production, interest rates from credits and classified credits (Stavárek, Vodová, 2010).

The phase of an uninterrupted growth of household indebtedness has lasted already since 1998, however a significant increase has been observed since the year of 2000. The year-toyear pace of the growth of the volume of credits granted to households oscillated about $30 \%$ from 2002 to 2007 . Since 2008 the pace of the growth has been decreasing and this trend has continued up to the present. In 2010 the debt of households with banks crossed the magic threshold of 1 trillion and last year it reached the sum of 1,093 billion Czech crowns (Bartošová, Novák, 2009; Czech national bank, 2012).The most characteristic feature of households contracting debts in the previous decade was the speed of this process. While the volume of household credits amounted to 120 billion Czech crowns in 2000, within 10 years it has grown eight times (Czech national bank, 2012).

One of the main reasons for increasing household indebtedness is the inability of households to create their own savings. An important indicator of the level of household indebtedness is the comparison between created savings and debts of households. At the moment households save up less than they used to in previous years. While in the nineties Czechs belonged to the thriftiest nations in Europe, the pace of the year-to-year growth of the volume of deposits with banks has definitely been slowing down (Czech national bank, 2012; Newbold, 1991).

People have different possibilities how to increase the value their savings. The most common method which increases the value of the savings deposits is to capitalize savings into bank deposits. The values of the volume of household credits and deposits for the last 19 years obtained from the Czech National Bank manifest an increasing trend of the volume of household credits and deposits (Czech national bank, 2012). An estimate of the development of credits and deposits of households in 2012 and 2013 was carried out using the trend function. The prediction was carried out with the significance level of $5 \%$. Based on this prediction executed in MS Excel program the values of estimated volumes of credits and deposits of households given in Table 1 were identified. The values are given in millions of Czech crowns. 
Table 1: The development of deposits and credits of households in years 1993-2010, including a prediction for 2012-2013

\begin{tabular}{|l|c|c|c|c|c|c|c|}
\hline & $\mathbf{1 9 9 3}$ & $\mathbf{1 9 9 4}$ & $\mathbf{1 9 9 5}$ & $\mathbf{1 9 9 6}$ & $\mathbf{1 9 9 7}$ & $\mathbf{1 9 9 8}$ & $\mathbf{1 9 9 9}$ \\
\hline Household deposits & 314048.1 & 375928.4 & 454949.0 & 521173.9 & $\begin{array}{r}626873 . \\
3\end{array}$ & 693543.6 & 699225.0 \\
\hline Household credits & 92781.1 & 107836.9 & 101789.4 & 103395.3 & $\begin{array}{r}104369 . \\
6\end{array}$ & 103602.9 & 108807.8 \\
\hline Household deposits & 743575.5 & 825793.6 & 837795.9 & 884830.0 & 951042.8 & 1010935.9 & 1113202.6 \\
\hline Household credits & 120209.0 & 136928.9 & 177365.3 & 234301.5 & 310793.8 & 411758 & 529925.3 \\
\hline Household deposits & 1231080.6 & 1373830.1 & 1484130.3 & 1579682.2 & $\begin{array}{r}1651354 . \\
2\end{array}$ & 1750108.0 & 1860141.2 \\
\hline Household credits & 707036.5 & 850678.3 & 939520.9 & 1026918.0 & $\begin{array}{r}1093725 . \\
0\end{array}$ & 1336904.1 & 1508176.0 \\
\hline
\end{tabular}

Comment: * the estimate of the development

Source: own processing according to Czech national bank: Client loans by sector. [quotation 2012-24-02].

Available at

WWW:<http://www.cnb.cz/cnb/STAT.ARADY_PKG.VYSTUP?p_period=12\&p_sort=2\&p_des=50\&p_sestuid $=7319 \& p \_u k a=6 \& p \_s t r i d=A B B A A \& p \_o d=200012 \& p \_d o=201112 \& p \_l a n g=E N \& p \_f o r m a t=0 \& p \_d e c s e p>$ and

Czech national bank: Households-Client deposits by type. [quotation 2012-24-02]. Available at WWW:

$<$ http://www.cnb.cz/cnb/STAT.ARADY_PKG.VYSTUP?p_period=12\&p_sort=2\&p_des=50\&p_sestuid=13646 $\& p \_u k a=1 \& p \_s t r i d=A B C A E \& p \_o d=200012 \& p \_d o=201112 \& p \_l a n g=E N \& p \_f o r m a t=0 \& p \_d e c s e p>$

A transparent graphic representation of the development of the volume of deposits and of the volume of credits in 1993-2011, including a prediction for 2012 and 2013, is presented in Graph 1. The graphic representation is supplemented with trend curves that indicate the predicted development of the volume of household deposits and credits for the period of the next two years. Based on the calculation of the determination index the quadratic function was chosen as the most suitable trend function. The determination index states what part of the variability of the monitored values can be explained via the given model. The value 0.986 therefore means that the reality of the development of the volume of deposits is described with the probability of more than $98 \%$. The determination index for the development of the volume of credits amounts to 0.9845 and thus the reality of the volume of household credits is also described with probability higher than $98 \%$. Therefore the chosen trend function appears to be very fitting for the development of both monitored indicators.

The quadratic trend function of the volume of deposits has the following formula:

$$
y=1890 x^{2}+32543 x+343248
$$

Using this quadratic trend function the predicted values of deposits for years 2012 and 2013 have been determined. For 2012 a rise by $5.9 \%$ is predicted, which means the total amount of 1,750,108 million Czech crowns deposited by households with banks. In 2013 the volume of household deposits should rise to the amount of 1,860,141 million, which represents a yearto-year increase by $6.3 \%$. 
The quadratic trend function of the volume of credits has the following formula:

$$
\mathrm{y}=5414.4 \mathrm{x}^{2}-50718 \mathrm{x}+185504
$$

Again, using this quadratic trend curve, the values of credits for years 2012 and 2013 have been determined. According to the prediction credits in 2012 should amount to 1,336,904 million and a year later already to 1,508,176 million Czech crowns.

The developmental trend of both quantities is clearly depicted in Figure 1. Quadratic regression lines for credits and deposits have been approaching one another in recent years, which mean that the volume of granted credits is getting alarmingly close to the volume of deposits. The prediction for the next two years indicates that the current trend will continue.

Figure 1: The development of household credits and deposits in years 1993-2010, including a prediction for years 2011 and 2012 (in mil. CZK)

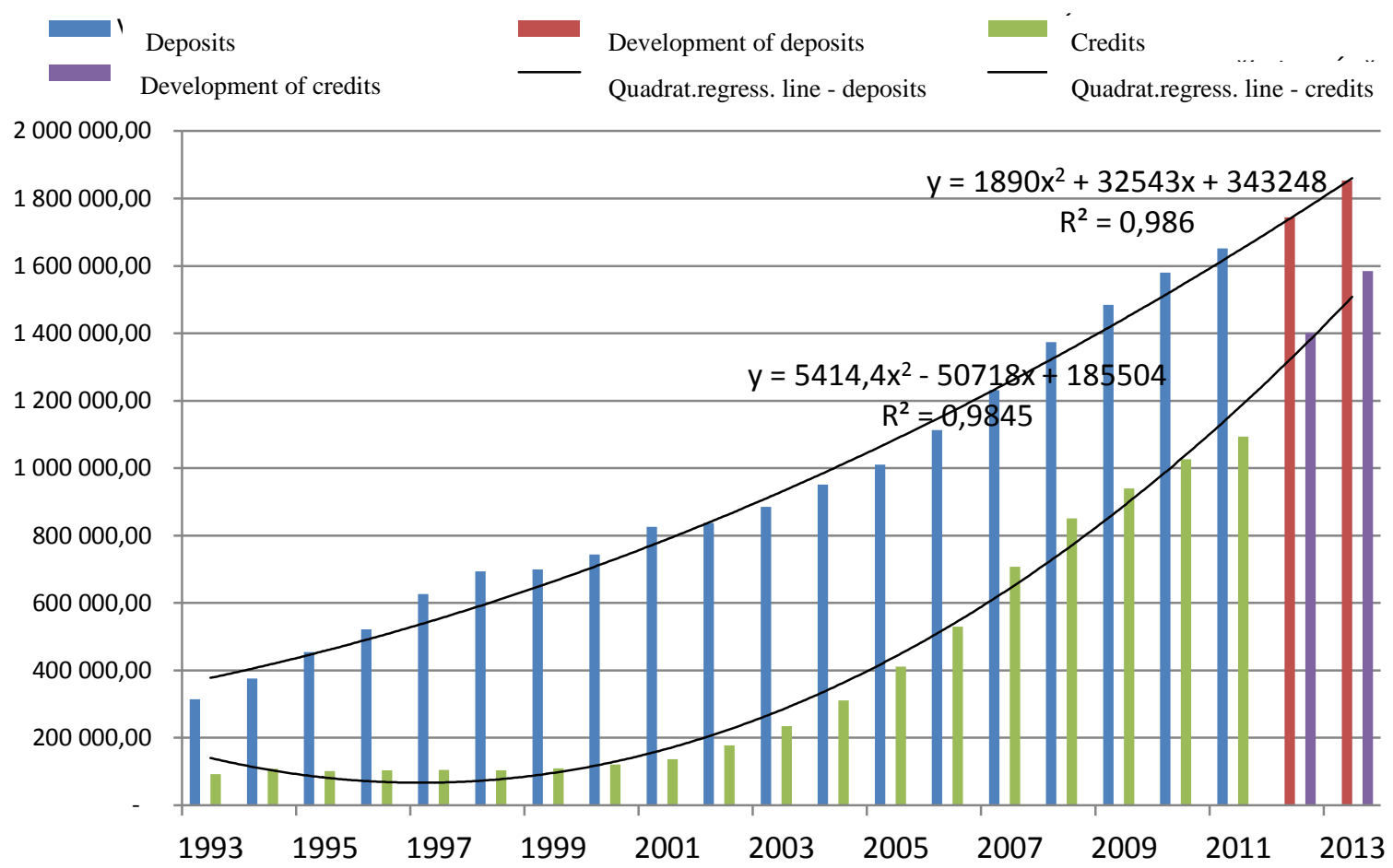

Source: [own processing according to Czech leasing and financial association: Zprávy o stavu a vývoji nebankovního, leasingového, úvěrového a factoringového trhu v ČR. [quotation 2011-09-14]. Available at WWW: http://www.clfa.cz/index.php?textID=64 and Czech national bank: Client loans by sector. [quotation 2012-24-02]. Available at WWW:

<http://www.cnb.cz/cnb/STAT.ARADY_PKG.VYSTUP?p_period=12\&p_sort=2\&p_des=50\&p_sestuid=7319 \&p_uka=6\&p_strid=ABBAA\&p_od=200012\&p_do=201112\&p_lang=EN\&p_format=0\&p_decsep>

\section{Household indebtedness from the viewpoint of age and income}

Data of the Czech Statistic office from the Family accounts statistics for years 2000 to 2010 were used for the analysis of indebtedness - these statistics monitor the economic activity of households and provide information about their expenses and the structure of consumption. Analysis of household indebtedness was executed from the viewpoint of the income and age structure of households.

\subsection{Analysis of indebtedness according to age groups}

The family accounts statistics divides population according to age into six groups. Young people up to 29 years of age belong to the first group, the second group is made up of people 
aged 30-39, the third group of people aged 40-49, the fourth group of people aged 50-59, the penultimate group contains people aged 60-69 and the last group is made up of people older than seventy years of age (Czech Statistical Office, 2011). This division has been used since year 2006, therefore data are only available for the last five years.

Figure 2 depicts the volume of credits of individual age groups for the period of 2006-2010. The axis $\mathrm{x}$ represents individual monitored years and the axis y oves values of the amount of credits per person expressed in Czech crowns.

Figure 2: Development of the volume of credits of individual age groups (annual averages per capita in CZK)

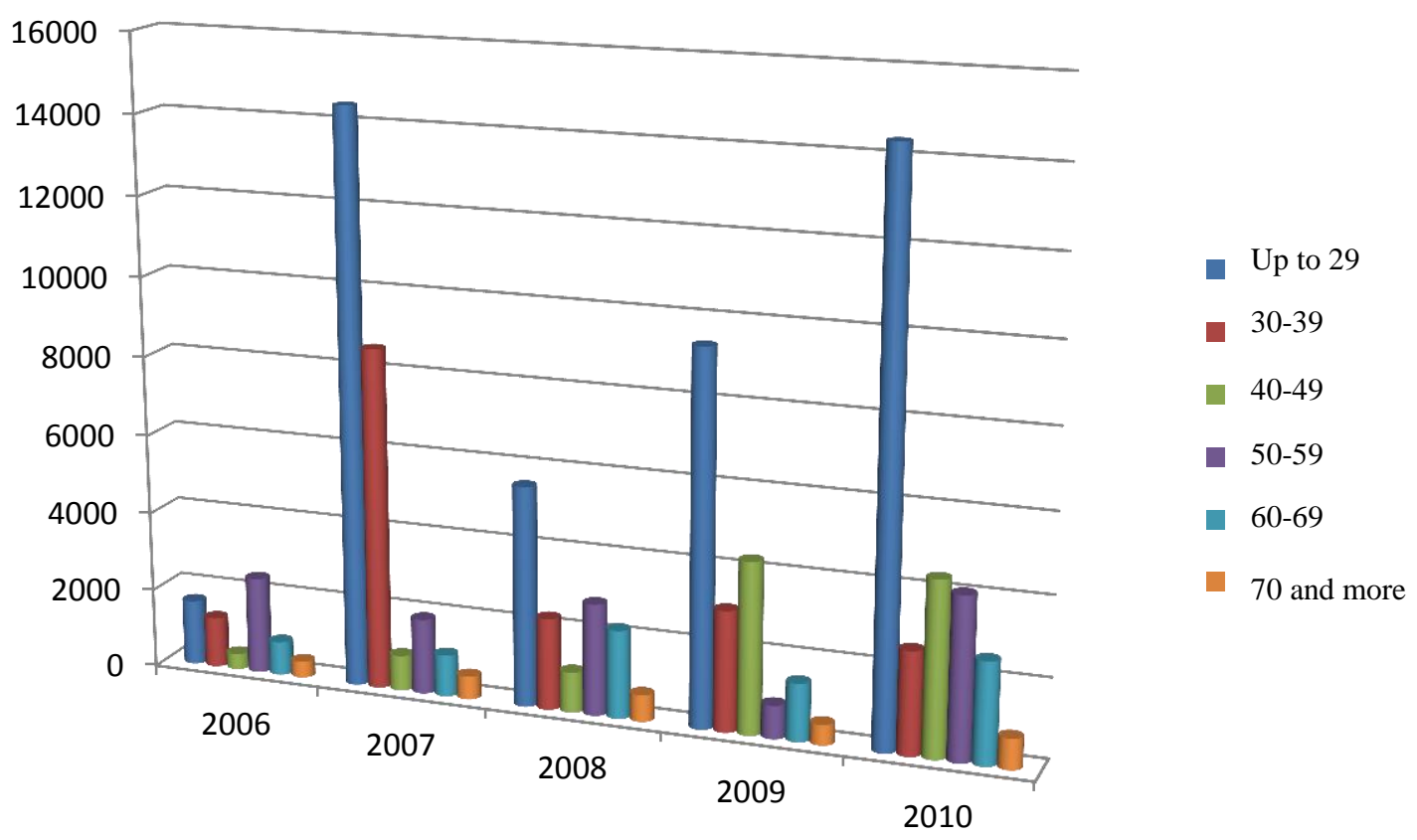

Source: own processing according to Czech statistical office: Expenditures and Consumption of Households included in Households Budget Survey in 2008-Households by Status and Age of the Head of Household, by Municipality Size Income Brackets. [quotation 2012-23-02]. Available at WWW: http://www.czso.cz/csu/2009edicniplan.nsf/engpubl/3001-09-

in_2008_households_by_status_and_age_of_the_head_of_household,_by_municipality_size,_income_brackets

The diagram shows that credits are used to the largest extent by the group of youngest persons, i.e. people up to 29 years of age. This finding is not in the least surprising: these people have not managed to save up financial means within their short lives and simply need to borrow money to secure accommodation and furniture and electronic devices for their flats. Credit growth in the years 2009 - 2010 in the group of 40-49 years was due to the growth of unemployment in this period. On the other hand, the group of the oldest people, i.e. people older than 70, has been borrowing the least every year.

The ability to save up is attributed by most people to older age groups. On the other hand the large volume of credits is not surprising with young people. However we can verify whether the aforementioned is really true in Figure 3 that shows how much a person from any given age group managed to save up in one concrete year. 
Figure 3: The development of the volume of savings of individual age groups (annual averages per capita in CZK)

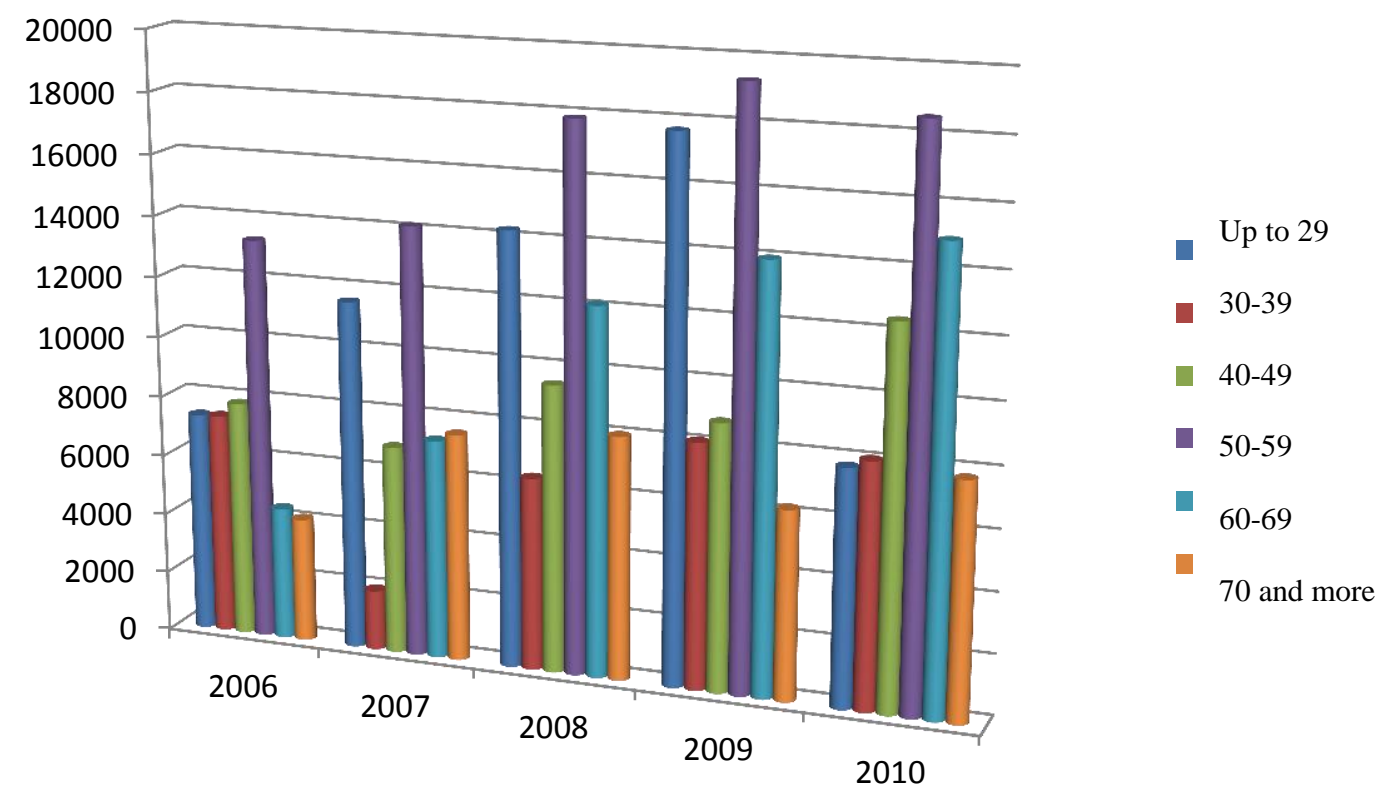

Source: own processing according to Czech statistical office: Expenditures and Consumption of Households included in Households Budget Survey in 2008-Households by Status and Age of the Head of Household, by Municipality Size Income Brackets. [quotation 2012-23-02]. Available at WWW:

<http://www.czso.cz/csu/2009edicniplan.nsf/engpubl/3001-09-

in_2008_households_by_status_and_age_of_the_head_of_household,_by_municipality_size,_income_brackets>

The fourth age group has clearly been managing to save up the largest amounts within the monitored period. People aged 50-59 saved up most in every of the monitored years. One of the main reasons for this can certainly be considered the fact that these people are approaching retirement and so create financial reserves for their old age. The same applies for the category of people aged 60-69, in which the volume of savings is significantly growing.

The amount of savings on the part of the group of the youngest population in years from 2007 to 2009 is striking. Within this period this group managed to save up the second largest amount of financial means out of all age groups of the population. Due to the fact that the same age group borrowed the highest amount of financial means in the same period this finding is surprising. It seems that young people do not neglect the need to have some means available, in case they have unexpected expenses, and they always find some means to create reserves.

\subsection{Analysis of indebtedness according to income groups}

The analysis of indebtedness according to income groups utilised the division of households according to the amount of the annual net income per person. Using this criterion Czech households were divided into ten groups, so called deciles. Thus the group "the lowest $10 \%$ " represents the group with the lowest annual income and the group "the highest $10 \%$ " logically represents the group with the highest annual income per person. For every group the upper limit of the annual net income is defined via which the group is specified (Czech Statistical Office, 2011).

All groups, including their upper income limits in individual year, are depicted in Table 2. 
Table 2: Division of households according to income groups

\begin{tabular}{|c|c|c|c|c|c|c|c|c|c|c|}
\hline year & $\begin{array}{l}\bar{w} 0^{0} \\
0 \\
0 \\
0\end{array}$ & 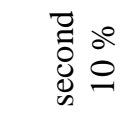 & $\begin{array}{l}\text { 를 } \\
\text { 음 }\end{array}$ & 预 & 㝴 & 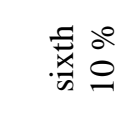 & 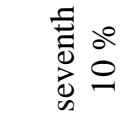 & 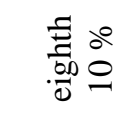 & 㔛 & 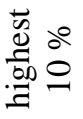 \\
\hline 2000 & 54484 & 63607 & 69160 & 74229 & 79321 & 85999 & 96402 & 112794 & 135148 & $\mathrm{x}$ \\
\hline 2001 & 58707 & 68092 & 74133 & 79649 & 85605 & 93733 & 104502 & 120828 & 146892 & $\mathrm{X}$ \\
\hline 2002 & 60130 & 70297 & 77718 & 83084 & 89494 & 96905 & 107073 & 124105 & 151967 & $\mathrm{x}$ \\
\hline 2003 & 63542 & 74745 & 81463 & 87215 & 93858 & 102032 & 114452 & 130530 & 161403 & $x$ \\
\hline 2004 & 66235 & 77509 & 84770 & 90598 & 97480 & 105783 & 116849 & 137358 & 168089 & $\mathrm{x}$ \\
\hline 2005 & 68736 & 80454 & 88242 & 95347 & 103188 & 112380 & 127248 & 147591 & 181440 & $\mathrm{x}$ \\
\hline 2006 & 70468 & 85695 & 94497 & 102577 & 110177 & 119743 & 134725 & 159205 & 193512 & $\mathrm{x}$ \\
\hline 2007 & 78071 & 92726 & 101790 & 110765 & 119326 & 130401 & 147639 & 169499 & 206028 & $\mathrm{x}$ \\
\hline 2008 & 85596 & 100065 & 109480 & 118809 & 127571 & 140648 & 158705 & 185950 & 225632 & $\mathrm{x}$ \\
\hline 2009 & 88205 & 105691 & 115099 & 124337 & 132912 & 145952 & 165557 & 194213 & 239508 & $\mathrm{x}$ \\
\hline 2010 & 91335 & 109008 & 119356 & 128520 & 137737 & 149986 & 170065 & 196112 & 244980 & $\mathrm{x}$ \\
\hline
\end{tabular}

Source: Czech statistical office: Expenditures and Consumption of Households included in Households Budget

Survey in 2008-Households by Status and Age of the Head of Household, by Municipality Size Income

Brackets. [quotation 2012-23-02]. Available at WWW:

$<$ http://www.czso.cz/csu/2009edicniplan.nsf/engpubl/3001-09

in_2008_households_by_status_and_age_of_the_head_of_household,_by_municipality_size,_income_brackets>

The volume of credits granted to the individual deciles is depicted in Figure 4. The values represent the identified mean value per person from a given group in CZK per year.

Figure 4: Development of credits in individual income groups

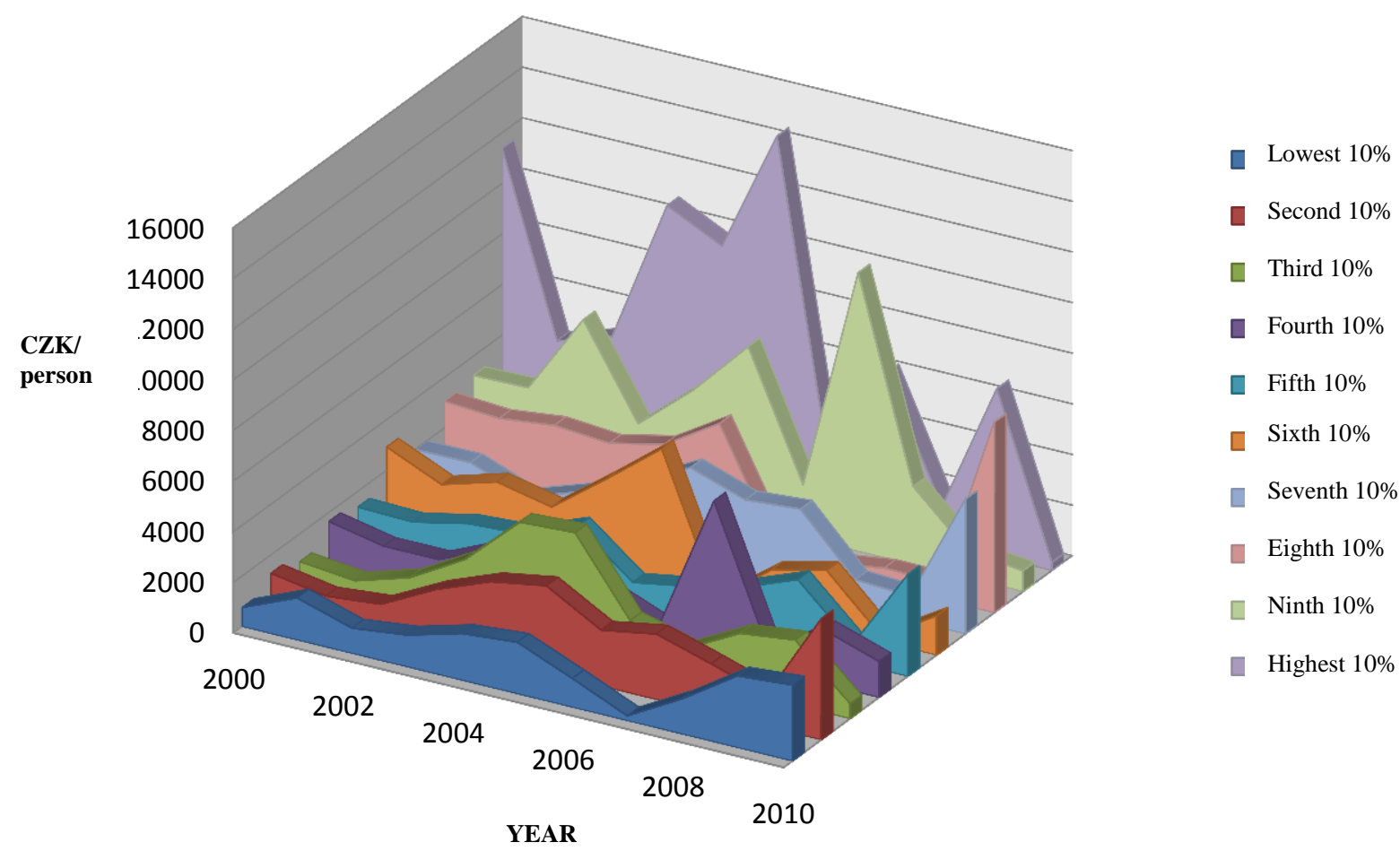

Source: own processing according to Czech statistical office: Expenditures and Consumption of Households included in Households Budget Survey in 2008-Households by Status and Age of the Head of Household, by Municipality Size Income Brackets. [quotation 2012-23-02]. Available at WWW:

<http://www.czso.cz/csu/2009edicniplan.nsf/engpubl/3001-09-

in_2008_households_by_status_and_age_of_the_head_of_household,_by_municipality_size,_income_brackets> 
The figure clearly shows the high volume of credits accepted by the group "highest $10 \%$ ", which borrowed the largest amount of financial means out of all groups for the monitored period. The main reason why groups with high incomes become indebted may be their high standard of living. At the same time these individuals demonstrate, as a rule, high creditworthiness and are able to pay off their liabilities properly and in time. These people are desirable clients for banks and therefore banks are willing to provide them with credits.

On the other hand groups with low incomes created lower debts within the monitored period. For instance the group "lowest $10 \%$ " borrowed the lowest volume of money five times within the monitored period, if we compare this group with the other groups. The cause of this is again the standard of living and creditworthiness, this time the low standard of living and low creditworthiness for bank institutions.

Figure 5: Development of savings in individual income groups

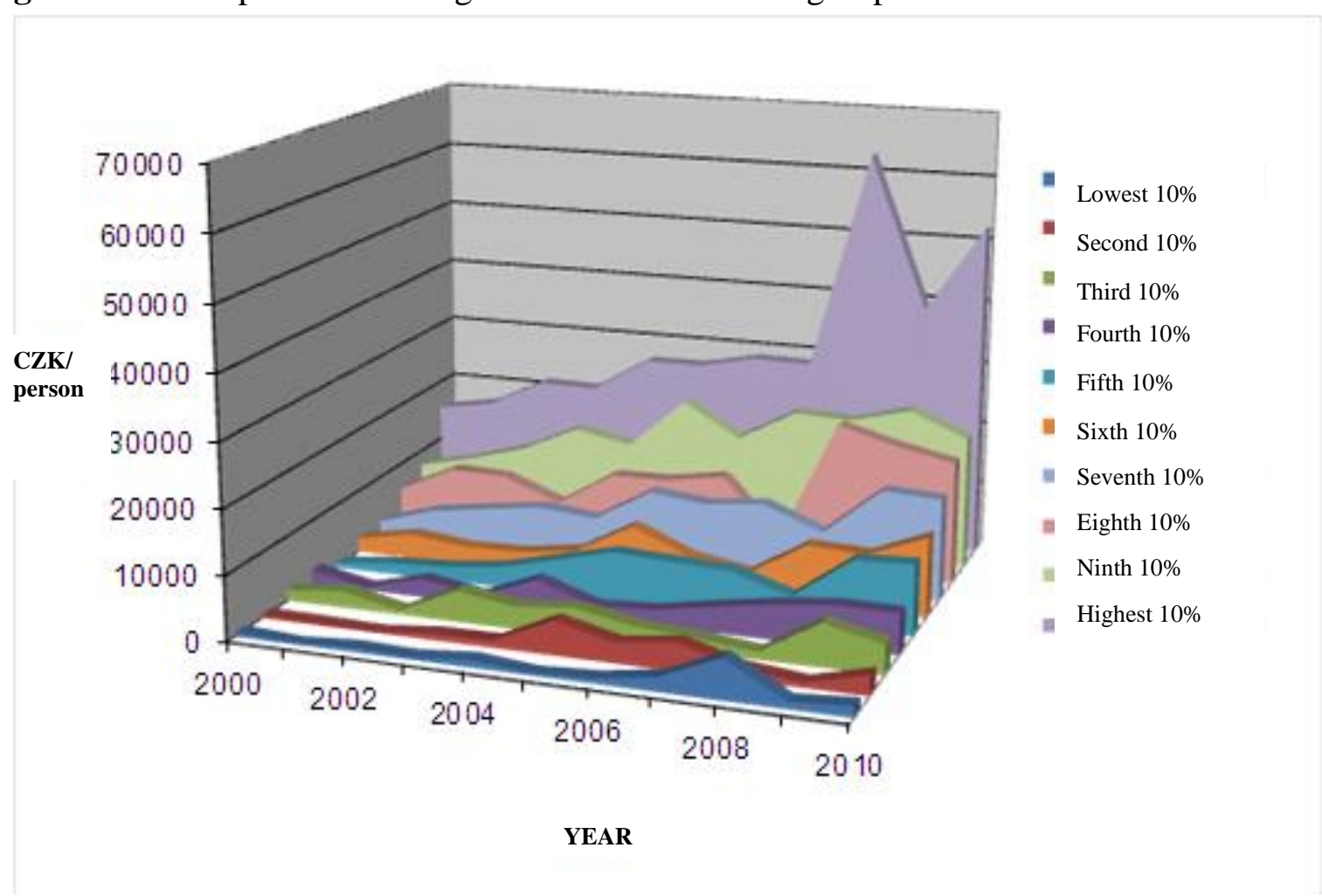

Source: own processing according to Czech statistical office: Expenditures and Consumption of Households included in Households Budget Survey in 2008-Households by Status and Age of the Head of Household, by Municipality Size Income Brackets. [quotation 2012-23-02]. Available at WWW:

<http://www.czso.cz/csu/2009edicniplan.nsf/engpubl/3001-09-

in_2008_households_by_status_and_age_of_the_head_of_household,_by_municipality_size,_income_brackets >

Figure 5 depicts the development of the volume of savings in all monitored income groups for the last eleven years. It is obvious that the groups of population with high incomes create the highest savings every year. The first place belonged to the group "highest $10 \%$ ". Even though the groups with high incomes contracted significant debts, they were able to save up considerable amounts of financial means.

\subsubsection{Cluster analysis}

Cluster analysis is generally used to assign units into groups (clusters) so that the units in the same group are more similar to each other than to those from the other groups. Cluster 
analysis was used to identify whether the use of this method on the basis of the known quantities will group together groups with a similar amount of the mean annual income. The objective is to identify whether the amount of income is related to the use of credits or to the ability to create savings or whether the amount of the mean annual income does not influence the volume of used credits or the ability to create savings.

Median values of mean annual incomes, credits and savings of the aforementioned ten income groups were calculated for the needs of cluster analysis. The values of these quantities are given in Table 3.

Table 3: Data of cluster analysis

\begin{tabular}{|c|c|c|c|}
\hline Income group & $\tilde{x}$ income & $\tilde{x}$ credits & $\tilde{x}$ savings \\
\hline Lowest 10 \% & 68736 & 1394 & 774 \\
\hline Second 10 \% & 80454 & 2210 & 1093 \\
\hline Third 10 \% & 88242 & 1749 & 2710 \\
\hline Fourth 10 \% & 95347 & 1574 & 2815 \\
\hline Fifth 10 \% & 103188 & 1790 & 5457 \\
\hline Sixth 10 \% & 112380 & 2134 & 4294 \\
\hline Seventh 10 \% & 127248 & 1994 & 8737 \\
\hline Eighth 10 \% & 147591 & 2985 & 11768 \\
\hline Ninth 10 \% & 181440 & 3237 & 17534 \\
\hline Highest 10 \% & $\mathrm{x}$ & 6232 & 26785 \\
\hline
\end{tabular}

Source:own processing according to Czech statistical office: Expenditures and Consumption of Households included in Households Budget Survey in 2008-Households by Status and Age of the Head of Household, by Municipality Size Income Brackets. [quotation 2012-23-02]. Available at WWW:

<http://www.czso.cz/csu/2009edicniplan.nsf/engpubl/3001-09-

in_2008_households_by_status_and_age_of_the_head_of_household,_by_municipality_size,_income_brackets>

The following statistical calculations as well as the graphic representation were created in the statistical program Statistica 10. The first step of the calculation of distances between individual objects, i.e. income groups in our case, is the calculation of the Euclidean distance according to the formula: (Newbold, 1991)

$$
d\left(X_{i}, X_{j}\right)={\sqrt{\sum_{k=1}^{p}\left(x_{i k}-x_{j k}\right)}}^{2}
$$

In our case $X_{i k}$ represents the value of the $k^{\text {th }}$ indicator in the $i^{\text {th }}$ income group and $X_{j k}$ represents the value of the $\mathrm{k}^{\text {th }}$ indicator in the $\mathrm{j}^{\text {th }}$ income group.

The first step for cluster analysis is to calculate a distance matrix $\mathrm{D}=\left\{d_{i j}\right\}$ which is symmetric and expresses the distance $\mathrm{d}\left(\mathrm{X}_{\mathrm{i}}, \mathrm{X}_{\mathrm{j}}\right)$ between individual couples. The higher the identified values of distances are the less similar the given income groups are. Another step of cluster analysis is the selection of a rule based on which clusters will be created. Out of several methods of clustering the method of complete connection of groups was selected. The procedure of clustering, including concrete distances between elements, is depicted by the dendrogram in Figure 6. The dendrogram represents a graphically clearly processed output of cluster analysis that provides information on the course of the grouping of analysed groups. 
The axis $\mathrm{x}$ gives consecutive numbers of income groups and the axis $\mathrm{y}$ gives distances between two grouped objects. Individual clusters characterise income groups with maximum similarity in the set factors, namely the volume of credits and savings.

Figure 6: Dendrogram of group analysis

\section{Structured diagram for 10 cases Weighted average of groups of pairs Euclidean distance}

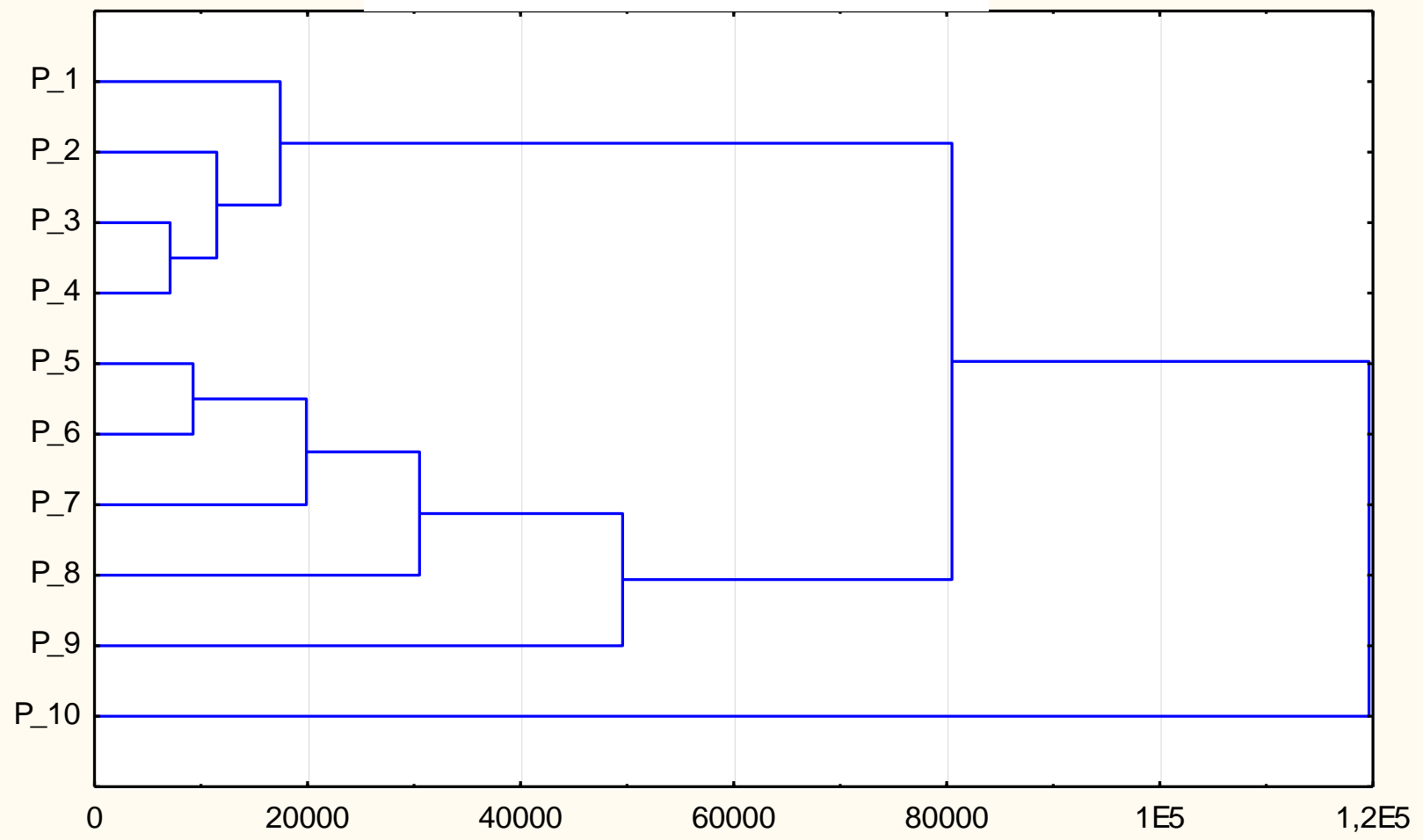

Distance of the connection

Source: Ministry of finance of the Czech republic: Zpráva o vývoji finančního trhu v roce 2009. [quotation 2011-09-03] Available at WWW:

<http://www.mfcr.cz/cps/rde/xbcr/mfcr/Zprava_o_vyvoji_FT_v_roce_2009_pdf.pdf>.

Gradual clustering created nine clusters. We can say that two carrying clusters were created that gradually put on other income groups and entire clusters. The smallest distance between objects was identified between objects $\mathrm{P}_{-} 3$ and $\mathrm{P}_{-} 4$, thus the third and the fourth income groups created a cluster and it can be said that these groups are most similar to one another in the monitored indicators. The program Statistica 10 continued the grouping of income groups in this way on the basis of similarity of median values of incomes, credits and savings. At first sight it is clear from the dendrogram that groups with low incomes grouped with other groups with low incomes. The situation with the groups with high incomes was similar. The last step of cluster analysis was clustering of the income group 10, that is, the group with highest incomes, to the other groups. A great distance of this group from the others is quite clear from the diagram at first glance, which indicates that this group is considerably different from the other income groups.

Even though cluster analysis linked all the income groups into a single final cluster, there is a significant distance between some groups. Income groups of similar mean annual incomes 
really clustered together first, which shows that the amount of annual income of households influences the volume of their credits or deposits.

\section{Conclusion}

The volume of bank deposits and bank credits was regularly growing within the monitored period. However the amount of borrowed financial means was growing significantly faster in recent years than was the case with deposited financial means. The largest excess of saved financial means over the borrowed financial means was recorded at the end of the nineties. Nonetheless the beginning of the new millennium brought a period of a significant increase in indebtedness and the year-to-year pace of growth of credits was approaching $30 \%$ in years 2002-2007. In the following years the year-to-year pace of growth of credits was not reaching such high values. However a decrease was also recorded for the year-to-year growth of household deposits with banks. It has been identified that the development of the volume of credits and deposits in the last year of 2011 followed the trend established in the previous decade. Furthermore it has been identified that the volume of granted credits is getting alarmingly near to the volume of deposits and the prediction for years 2012 and 2013 has shown that this trend will continue in these two years.

The analysis of household indebtedness from the viewpoint of income has resulted in many surprising findings. A substantial part of the volume of credits during the monitored period was granted to the group with the highest mean annual incomes. However at the same time this group managed to save up significant amounts every year during the monitored period. This combination of high volumes of accepted credits and high savings sets this group apart from the other income groups. The divergence of the group with the highest incomes from the other groups has been verified by executed cluster analysis. This analysis has also confirmed the dependence of the volume of used credits and the amount of deposits on the mean annual income of households.

From the viewpoint of age credits were used to the largest extent by the group of the youngest persons, i.e. people aged up to 29 years of age during the followed period. On the other hand the group of the oldest people, that is, people aged 70 and more, were borrowing the least during the monitored period. The analysis of savings has shown that the group of people aged 50-59 was creating the largest savings during the monitored period. This may be mainly explained by the fact that this group is approaching their retirement and so these people create financial reserves for their old age.

\section{References}

[1] BARTOŠOVÁ, J. a NOVÁK, M., 2009. Analýza ekonomického chování sektoru domácností $v$ České republice z hlediska zadluženosti. Conference International statistic and economic days at University of Economics. Praha: VŠE. ISBN 978-80-86715-66-9. Available at: 〈http://mi.fm.vse.cz/soubory/bartosova/db/Bartosova_Novak_MSED2.pdf>.

[2] ČERNOHORSKÝ, J., G. SERDAREVIĆ a P. TEPLÝ, 2010. Theoretical background for competitive merger analysis. In Scientific Papers of the University of Pardubice, Series D, vol. 16, no.1 pp. 50-58. ISSN 1211-555X.

[3] CZECH LEASING AND FINANCIAL ASSOCIATION, 2011.Zprávy o stavu a vývoji nebankovniho, leasingového, úvěrového a factoringového trhu v ĆR. [quotation 2011-0914]. Available at WWW: 〈http://www.clfa.cz/index.php?textID=64>. 
[4] CZECH NATIONAL BANK, 2012. Client loans by sector. [quotation 2012-24-02]. Available at WWW:

http://www.cnb.cz/cnb/STAT.ARADY_PKG.VYSTUP?p_period=12\&p_sort=2\&p_des=5 0\&p_sestuid=7319\&p_uka $=6 \& p \_s t r i d=A B B A A \& p \_o d=200012 \& p$ do=201112\&p_lang= EN\&p_format $=0 \& p \_$decsep $=$.

[5] CZECH NATIONAL BANK, 2012. Households-Client deposits by type. [quotation 201224-02]. Available at WWW:

http://www.cnb.cz/cnb/STAT.ARADY_PKG.VYSTUP?p_period=12\&p_sort=2\&p_des=5 0\&p_sestuid=13646\&p_uka=1\&p_strid=ABCAE\&p_od=200012\&p_do=201112\&p_lang $=\mathrm{EN} \& \mathrm{p} \_$format $=0 \& \mathrm{p} \_$decsep $=$.

[6] CZECH STATISTICAL OFFICE, 2011. Expenditures and Consumption of Households included in Households Budget Survey in 2008-Households by Status and Age of the Head of Household, by Municipality Size Income Brackets. [quotation2012-23-02]. Available at WWW: http://www.czso.cz/csu/2009edicniplan.nsf/engpubl/3001-09in_2008_households_by_status_and_age_of_the_head_of_household,_by_municipality_si ze,_income_brackets

[7] HRONOVÁ, S. a R. HINDLS, 2008. Ekonomické chování sektoru domácností ČR: spotřeba a zadluženost. Statistika, no. 3, pp. 189-204. Available at WWW: <http://panda.hyperlink.cz/cestapdf/pdf08c3/hronova.pdf>

[8] LINHARTOVÁ V., 2010. Analýza zadluženosti českých domácností. Dissertation. Pardubice: University of Pardubice106 p.

[9] MINISTRY OF FINANCE OF THE CZECH REPUBLIC, 2009. Zpráva o vývoji finančního trhu $v$ roce 2009. [quotation2011-09-03] Available at WWW: <http://www.mfcr.cz/cps/rde/xbcr/mfcr/Zprava_o_vyvoji_FT_v_roce_2009_pdf.pdf>.

[10] NEWBOLD, P, 1991. Statistics for Business and Economics. London, Prentice-Hall Int. Lim. ISBN 0138506450

[11] STAVÁREK, D. a P. VODOVÁ, 2010. Aplikace nerovnovážného modelu na trh úvěrů v České republice. In Ekonomie a management. 2010, vol. 13, no. 4, pp. 96-109. ISSN 12123609 